\title{
Massilia and Early Celtic Culture
}

\author{
by J. M. DE Navarro
}

$\mathrm{H}$

ALLSTATT and La Tène are the names given to the first and second phases of the pre-Roman Iron Age. They are derived from the sites where objects characteristic of the respective cultures were first identified, neither Hallstatt nor La Tène having any claim to be considered as the cradles of the cultures named after them. The former lies in Upper Austria. La Tène ("the shallows') is situated in Switzerland at the eastern end of the lake of Neuchatel.

The upper limit for the chronology of the Hallstatt Period is a vexed point. If by Hallstatt we mean a period when iron was in general use, it can hardly have said to have begun before the ninth century B.c.; if we regard it as denoting the time when Villanovan ${ }^{1}$ and other contemporary influences first made themselves felt in Central Europe, it can hardly have begun later than $c$. I000 B.C. Reinecke would even put it back as far as $c$. I200 B.C. The lower limit is somewhat easier to define. Generally speaking it came to an end $c .55^{0-500}$ B.C. ; but in some districts it persisted until c. 400, while in north-east Germany and other remote areas, the La Tène culture cannot be said to have succeeded it until $c$. I 50 B.C., or even later.

Reinecke divides the Hallstatt period into four phases; Déchelette into two. ${ }^{2}$ It is with Reinecke D, which roughly corresponds to Déchelette II, that we are concerned. The dates assigned to this phase are given as follows :-

Reinecke, $c .700-550$ B.C. and in some districts later; Déchelette, c. 700-500 B.C.

The art of the Hallstatt Period, for the most part rigidly geometric, is largely the outcome of Bronze Age sources, though a tendency towards figural ornamentation, derived from Italy, also asserts itself. But if one may generalize, the Hallstatt style is mainly an exaggerated

${ }^{1}$ For account of Villanova period see D. Randall-MacIver in ANTrQuity (I928) II, pp. I34-I40.

${ }^{2}$ For Reinecke, see his articles on the four Hallstatt phases in Lindenschmidt's Altertümer unserer heidnischen Vorzeit $(=\mathrm{AuhV})$ v, pp. 144, 231, 235, 315 and 399 ; For Déchelette see his Manuel, II, 2, p. $622 \mathrm{f}$. 


\section{ANTIQUITY}

development of older influences. Not until it was in its last phase did the Hallstatt world really come into contact with Greece.

The La Tène culture first came into being $c .550$ to 500 B.C.; in Switzerland, and in the south-westernmost parts of southern Germany not until c. 400. Paul Reinecke who, more than any other authority, has contributed to our knowledge of this period, divides it into four phases $\mathrm{A}-\mathrm{D},{ }^{3} \mathrm{~A}$ and $\mathrm{B}$ corresponding to Déchelette $\mathrm{I} ; \mathrm{C}$ and $\mathrm{D}$ to Déchelette II and III. The importance of this twofold division of La Tène I has not yet been fully grasped by English and French archaeologists : with the possible exception of the bronze bowl from Cerrig-yDrudion (Ant. Four. (1926) vI, p. 277), phase A is unrepresented in these islands; not so in France. Without recognizing this subdivision of La Tène I, it is hardly possible to obtain a clear idea of the genesis of the La Tène culture. The phase which most concerns us is phase A. This, according to Reinecke, began $c .55^{\circ}$ and ended $c .425$ or 420 B.C. ${ }^{4}$

The genesis of the La Tène style was due to a fusion of older elements, with more or less contemporary Greek influences. The former were technical as well as stylistic; the latter, chiefly stylistic. The plant-motifs, which, with their geometrical derivatives, are the most characteristic feature of La Tène art, are mainly derived from classical prototypes - the palmette, free-tendril and other patterns. The zoomorphic and anthropomorphic elements mostly date from phase A.

The zone in which the culture of La Tène A held dominion extends roughly from eastern France to Bohemia. For convenience, it may be divided into a Central, a Western and an Eastern area. The first consists of the Middle Rhenish and adjacent regions, and is best represented by the famous group of burials known as the 'Chieftains' Graves ', with their rich tomb-furniture of gold and bronze ornaments, their weapons and imported bronze vessels of Greek or Graeco-Italian manufacture. The Western area lies in east and north-east France. The rich chariot-burials of the Marne region mostly date from phase $A$. Here Greek or Graeco-Italian bronze vessels occur, though not in

${ }^{3}$ See his important study Zur Kenntniss der La Tène-Denkmäler, der Zone nordzuärts der Alpen, in the 1902 Festschrift des Römisch-Germanisches Central-Museum zu Mainz (=Mainzer Festschr, 1902).

${ }^{4}$ Bayerischer Vorgeschichtsfreund (1925) v, p. 49 f. Schumacher's dates for this phase are:-from the end of the sixth century to $c$. 400 в.C.; see Ebert's Reallexikon, viii s.v. Mittel-und Süddeutschland, p. $266 \mathrm{f}$. Déchelette assigns the fifth and fourth centuries to his La Tène $\mathrm{r}$, see his Manuel, $\mathrm{II}, 3$, p. $930 \mathrm{f}$. 


\section{MASSILIA AND EARLY CELTIC CULTURE}

such profusion as in the Rhenish Chieftains' Graves. Greek pottery has come to light on several sites in the Western and Central areas. ${ }^{5}$ The Eastern area (east Bavaria, west Bohemia and southern Thuringia) in certain respects differs fundamentally from the other two. Reinecke observed these differences over a quarter of a century ago, ${ }^{6}$ and considered that they were due to our Central and Western areas being subject to Greek influence which came by way of the Hellenic colonies in southern France, while the Eastern area (where the Greek influence is far less strongly felt) derived its southern inspiration mainly from Italy, by way of the Adige-Brenner route. Since then Déchelette and others have challenged the view that the Greek influence from southern France reached the La Tène zone prior to $c .300$ B.C. And although little has been written on this subject in recent years, these criticisms have won increasing support.

With the downfall of its great Bronze Age civilization, the east Mediterranean area ceased to have any great influence on the cultures of Central Europe, but after an interval of approximately five centuries, during the last phase of the Hallstatt Period, the influence from Greece ( $\mathrm{I}$ use the word in its widest sense, including the whole area of Hellenic colonization) made itself felt once more. It can best be traced in a small group of imported metal objects and pottery, found in France, Switzerland and south-west Germany, associated with antiquities dating from phase $D$ of the Hallstatt culture (Déchelette's Hallstatt II). A short summary of these imports is necessary before attempting to determine the direction by which that Greek influence reached Central Europe.

A. Metal ObJects. (Finds marked with an asterisk denote tumuli with chariot-burials).

I. Bronze vases. Bronze tripod and bowl ornamented with bronze griffons' heads :? La Garenne, near Chatillon, Cote d'Or* (Déchelette, l.c., II, 2, p. 647).

${ }^{5}$ For convenience sake I shall allude to the above Western and Central areas as the Celtic Zone, for there is good reason to believe that during the latter part of Hallstatt $\mathbf{D}$ they formed part of the area occupied by the Celtic peoples (see my 'Coming of the Celts' in the Cambridge Ancient History, vII, p. $54 \mathrm{ff}=\mathrm{CAH}$, vII.) Whether the above Eastern area was already settled by Celtic peoples or not is still a matter of dispute.

${ }^{6}$ Mainzer Festschr., I902, p. 56 f.

7 These and the griffon's head from Sens were undoubtedly of Greek manufacture (cf. Déchelette, l.c., II, 2 figs. 22r and 223). If these heads are of Ionian workmanship, they doubtless reached the Celtic area by way of Massilia: Massilia was a Phocaean colony and Phocaea was one of the principal cities of Ionia. See Reinecke, AuhV, v, p. 329. Compare also Herodotus, Iv, ${ }_{52}$. 


\section{AN'TIQUITY}

A bronze 'hydria': Grächwyl, Canton Berne,* see plate $\mathrm{I}$. (Tschumi, Urgesch. des Schweiz, p. II6).

The early wine flagons on pedestals, with trilobe mouth and bulging body, see fig. I : Kappel (Baden)*-handle and pedestal only (Wagner, Fundstätten und Funde, I, p. 21 I). Vilsingen, Hohenzollern*-also in fragments, see plate II. (Zeitschr. für Ethnologie, I900, p. (482)). L'Agnel near Pertuis, Vaucluse (L'Homme Préhistorique, 1909, p. 204, cf. Déchelette, l.c., II, 2, fig. 308.3).

A griffon's head similar to those from La Garenne was found at Sens, Yonne (Déchelette, l.c., II, 3, p. I 598).

The bronze bowls with beaded rims, found at Hundersingen,* Portalban, etc (see Reinecke, AuhV. v, p. 328, f. no. 1033), though originally Greek types, may have been copied elsewhere.

The same may apply to the large bronze cauldrons with iron ring handles discovered at Hundersingen* and Klein Aspergle, Württemberg, etc. (Ibid. p. 329, no. 1034).

2. Weapons. Greek javelin heads of an early type were found on the following sites:- Pourrières, near Marseilles, Camp du Rouret, Alpes Maritimes and in a Late Hallstatt tumulus at Alaise, Doubs (see Clerc, Massalia, r, p. 258).

M. Clerc tells me that a Greek helmet of the sixth century has recently been found in Vaucluse. A Greek greave was found at Roquefort, Alpes Maritimes (Clerc, l.c., I, p. 259 f.).

B. PotTERy. Greek pottery has been found on a number of sites in southern France (see Clerc, l.c., I, p. $34^{\circ} \mathrm{ff}$.); among other finds, a Protocorinthian cup was unearthed in a Late Hallstatt tumulus near Pertuis, Vaucluse (see Déchelette, l.c., II, 2, fig. 252), and a lecythos with black palmettes at Voiron, Isère (Bull. de Corresp. Hellenique, I 884 , p. I93).

The finds from the Camp de Château-sur-Salins (Jura) are of greater importance. The Camp de Château is a fortress dating from the end of the Hallstatt and the earliest La Tène period, a stratified site carefully excavated by M. Piroutet. ${ }^{8}$ Fragments of red- and blackfigured Attic vases and of unpainted Greek amphorae were found with Late Hallstatt fibulae and other antiquities. The Camp de Château, though perhaps the most important, is not the only site in that region

${ }^{8}$ Revue Archéologique (=RA) I909, I, pp. $193 \mathrm{ff}$. 
PLATE I

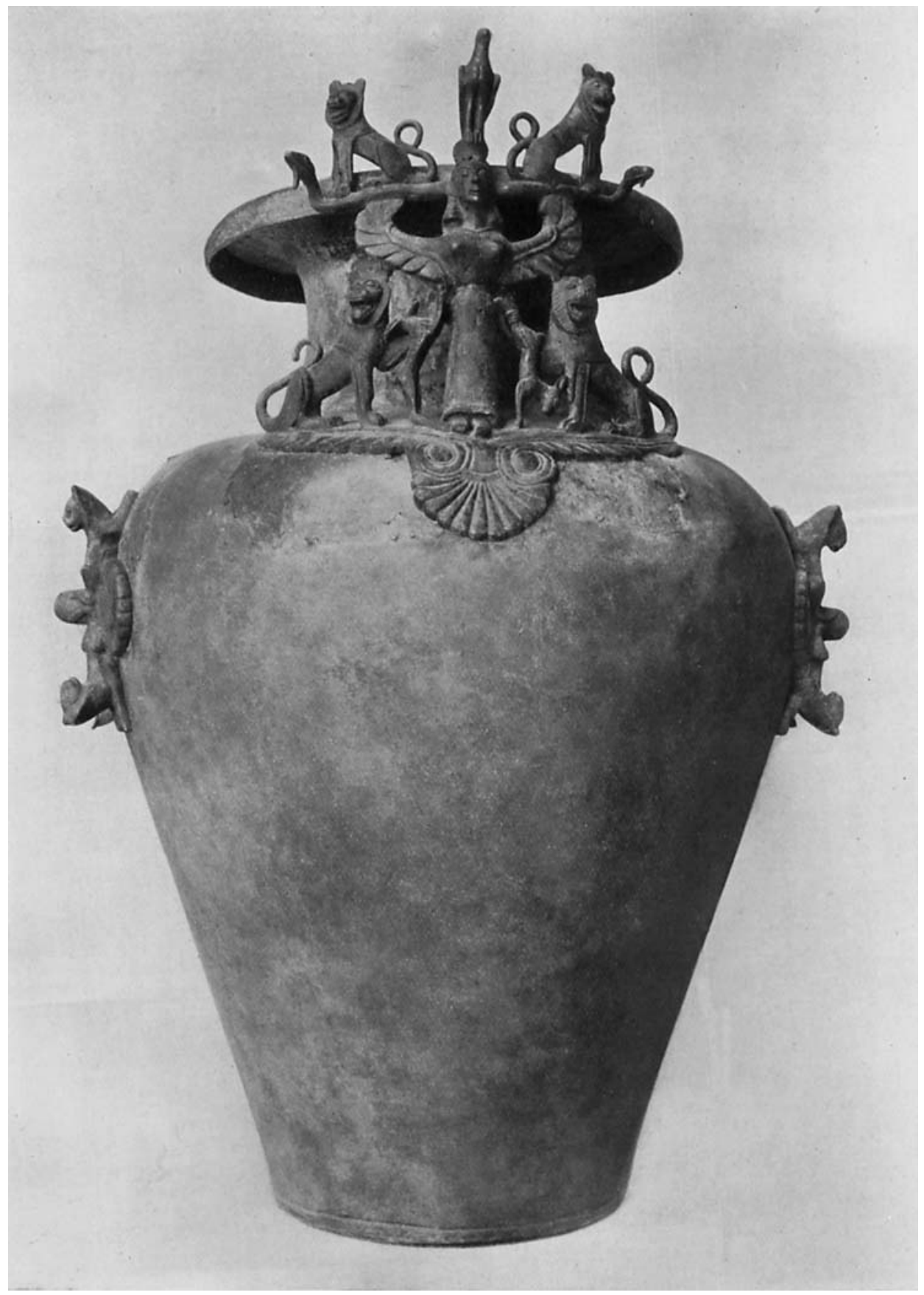

THE ' HYDRIA' FROM GRACHWYL (CANTON OF BERNE)

By courtesy of the Bernisches Historisches Museum Authorities

facing $p .426$ 
PLATE II

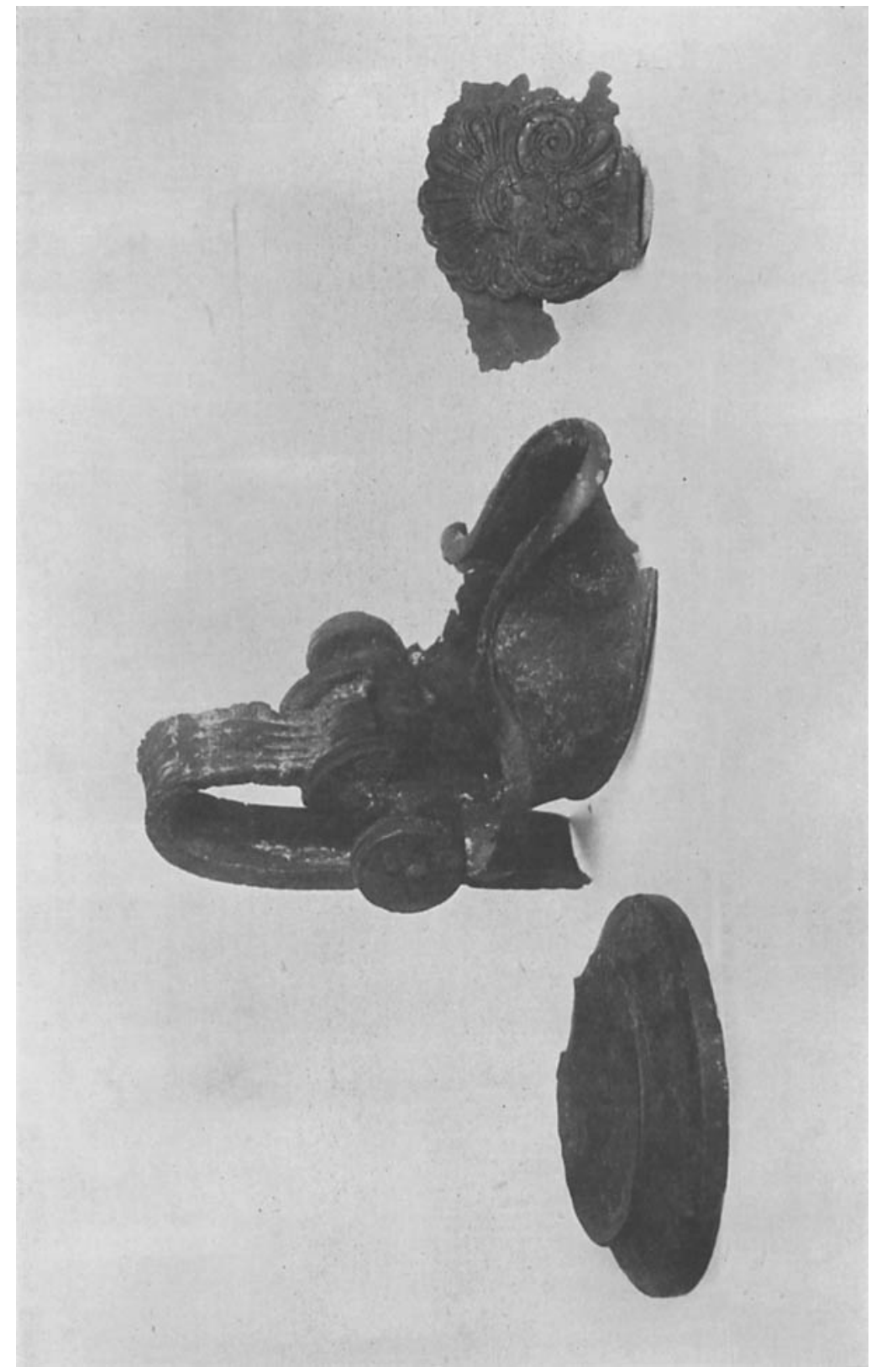

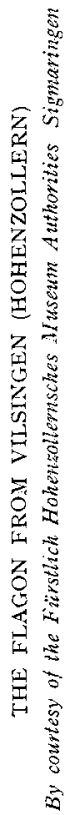




\section{MASSILIA AND EARLY CELTIC CULTURE}

which yielded Greek pottery. Three Greek amphorae were found in another Jura camp, Mont-Guérin; several in the tumuli at Mantoche (Hte. Saône) and one in a barrow at Mercey-sur-Saône (Hte. Saône). ${ }^{9}$ The last two sites Déchelette assigns to his first La Tène Period. The above group of antiquities are nearly all found in Hallstatt contexts and date from the seventh and sixth centuries.

During La Tène A, this Greek (or ultimately Greek) influence attained to a still greater importance. There is a whole series of imported bronze objects in the Celtic area, stamnoi (see plate III), wine flagons no longer with round pedestals and trilobe mouths, but with flat bases and beaked spouts (hence the German name Schnabelkannefig. 2), and other types. Further to the east, their occurrence is more sporadic. A full inventory with a map (the geographical positions of some of the sites on the latter are inaccurate) is given in the last of the four volumes of Déchelette's Manuel (p. $\left.{ }_{599} \mathrm{ff}.\right){ }^{10}$ It is yet to be seen how far these vessels are of Greek or Graeco-Italian (Greek colonies in Italy) workmanship, and how far they are Etruscan or wholly barbaric copies; the last-named are easier to distinguish (e.g. the beaked flagon from Klein Aspergle). But the influence of the late archaic and classical Greek styles upon more or less contemporary Celtic art is very strong, whether more directly transmitted through Massilia by way of the Rhône, or less directly through barbaric, Etruscan or Italian copies. This is particularly noticeable during phase A of the La Tène Period. Yet side by side with fairly faithful imitations of Greek ornamental motifs, we already begin to meet with a conscious stylizing of the classical prototypes. In the ensuing phases, this process grew so marked that it is often difficult to recognize the classical parentage of many of the Celtic designs. This, no doubt, is partially due to the very noticeable decrease in the number of classical imports found in the trans-Alpine regions during La Tène $B .{ }^{11}$

Having given a brief sketch of these Late Hallstatt and Earliest La Tène imports, let us try to retrace the routes along which they passed, beginning with the Hallstatt group.

Leaving aside the Adige-Brenner-Elbe highway which, even at the time we are speaking of, had linked up Italy with Jutland for at

${ }^{9}$ L'Anthropologie (1918-19) xxix, p. 222 ; Déchelette, l.c., II, 3, p. 1047 f.

10 The French material for the map in this article is partly based on the above, and partly on Joulin (RA, I9ro, II, p. I ff.) and Clerc's Massalia, I).

${ }^{11}$ Greek coins first appear in the Celtic area during this phase, and payment by coin may have somewhat affected the more primitive method of trade by barter. 


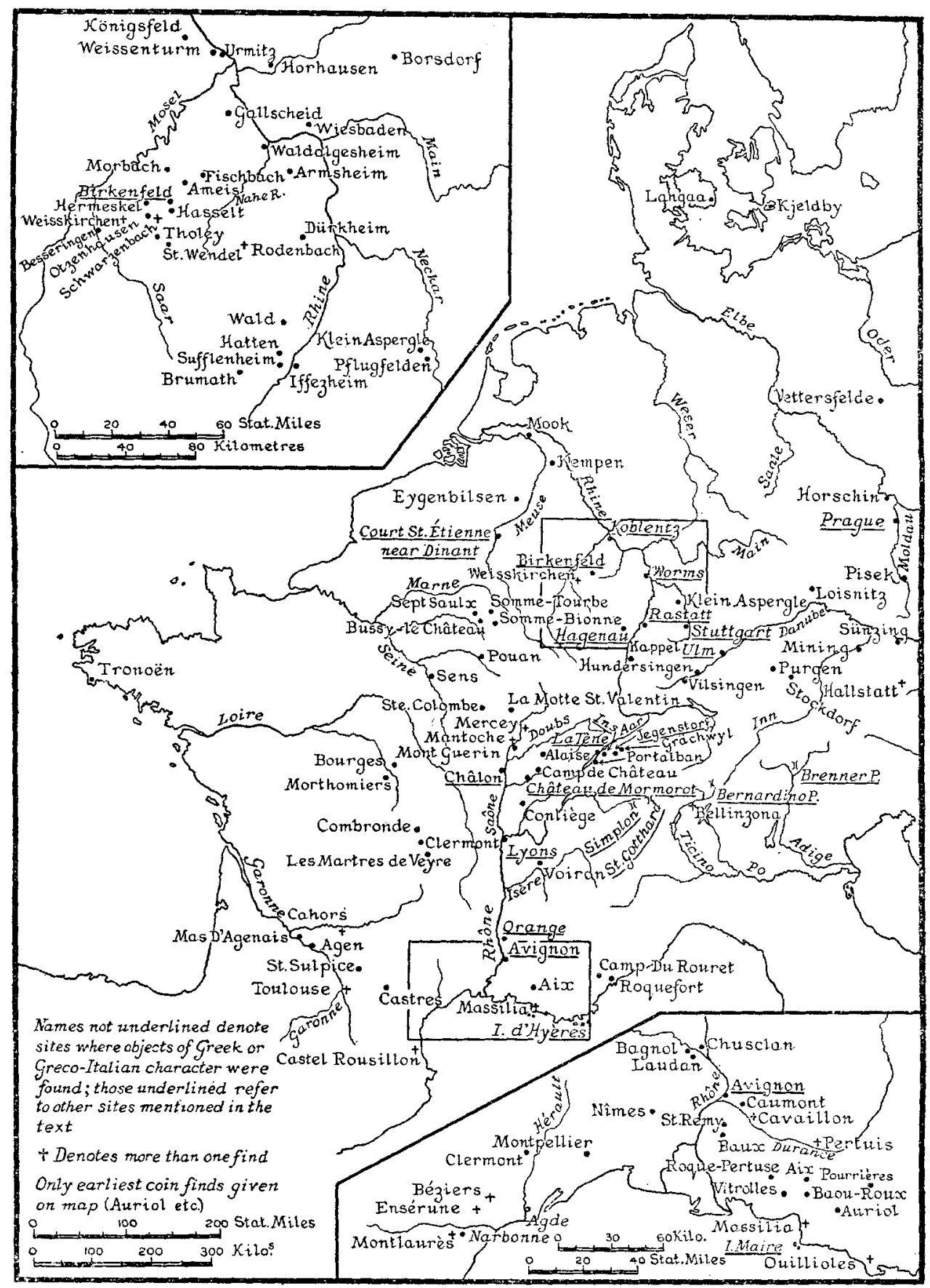

THE DISTRIBUTION OF GREEK AND ITALO-GREEK IMPORTS IN THE TRANSALPINE AREA

(HALSTATT D-LA TÈNE B) 


\section{MASSILIA AND EARLY CELTIC CULTURE}

least a thousand years, ${ }^{12}$ and along which the Italian stimulus reached the Eastern La Tène A area, two main routes are open to discussion : the Ticino-Mesocco-Bernardino-Rhine and the route which passed up the Rhône from southern France. The Simplon and St. Gotthard passes, partially owing to the bad Sub-atlantic climate conditions (see below p. 442), were of no importance at this period; and although the route over the Great St. Bernard was in existence the evidence does not warrant our regarding it as one of the main cultural highways between Italy and the barbaric North. ${ }^{13}$

It has been argued that the 'hydria' reached the Berne area from Italy by way of the Ticino-Rhine route. But, from a purely geographical point of view, the latter would be a devious way for a Greek import made in south Italy to reach that district. It should also be noted that this 'hydria' belongs to a cycle of forms unknown to Upper Italy. The most northerly objects which show any stylistic resemblance to the Grächwyl 'hydria' are the bronze handles cited by Neugebauer from the Miarche region. ${ }^{14}$ The 'hydria' is considered by Neugebauer as having been made under Peloponnesian (probably Laconian) influence in one of the Greek workshops of southern Italy.15

Turning to the pottery, we have as yet only one connecting link between Provence and Lyons-the lecythos decorated with black palmettes from Voiron. But north of that zone finds of this nature are better represented. We have already alluded to the Greek amphorae found at Mantoche, Mercey, Mont Guérin and the Camp de Château. Furtwängler pronounced the amphora from Mercey and one of those discovered at Mantoche to be of pure Greek manufacture, and, in assigning them to the sixth and fifth centuries, noted that they corresponded in form to representations of amphorae on red-figured vases of the severe style. ${ }^{16}$ The finds from the Camp de Château furnish evidence of a yet stronger nature. At a slightly lower level than the

${ }^{12}$ See Geograph. Fournal (1925) Lxvi, pp. $484 \mathrm{ff}$.

${ }^{13}$ Although coin-finds show that an overland-trade existed between Massilia and Upper Italy in the fourth century, there is little evidence for close relations between those regions over the West Alpine passes during the Hallstatt $\mathrm{D}$ and La Tène A phases.

${ }^{14}$ Römische Mitteilungen (1920) xxxv, p. 403 f. (cf. Randall-MacIver, Iron Age in Italy, pl. 30 and p. I34).

${ }^{15}$ Archaeolog. Anzeiger, 1925, cols. 183-8 and 204.

${ }^{16}$ RA. (r909), I, p. 209. One of the fragments from Mont Guérin was of a ware identical with the amphora from Mercey. 


\section{ANTIQUITY}

stratum which yielded black-figured Attic ware (vith century) sherds were found of wheel-made pottery decorated with undulated lines, and indigenous to Lower Provence. ${ }^{17}$ Examples of this 'Ligurian' pottery were discovered at Château de Mormorot (Jura), and at Court St. Etienne (near Dinant in Belgium) in a late Hallstatt burial.

From the above it is clear, as Piroutet has already observed, ${ }^{18}$ that trade relations were in existence during the sixth century between the Greek colonists in southern France and the Celtic population of the Saône-Seille-Doubs area, relations in which the Ligurians probably acted as middle-men. But did this trade effect southern Germany ?

Although that area might appear to have been supplied by the Bernardino-Rhine route, the distribution of the earlier wine-flagons (Pertuis, Kappel, Vilsingen) and the bronze javelin-heads (Camp du Rouret, Pourrières, Alaise) points to the Greek influence having reached south Germany from southern France. Neither of these types has come to light in Upper Italy. From a geographical standpoint there is nothing to prevent the route which linked up the Franche Comté and southern Germany from proceeding along the Doubs to the Montbéliard region and on through the gap of Belfort to the Rhine. ${ }^{19}$ In this connexion it should be noted that close cultural relations existed during the Hallstatt period between Württemberg and the Alaise district ; ${ }^{20}$ and Alaise, with its thousands of Hallstatt tumuli, lies in the department of Doubs, at no great distance from Salins, overlooking which stands the Camp de Château, the stratified site which yielded the important finds of Greek pottery and the 'Ligurian' sherds.

Further to the west, the evidence is less striking, but we have the bronze griffon's head from Sens. The distribution of sixth century and later southern imports in south-west France, points to a route along the Garonne (see below pp. 433, 437). Some of the imports referred to above (on p. $425 \mathrm{f}$ ) were actually made in the seventh century. The earliest Greek pottery found at Fort St. Jean (on the north side of the old harbour of Massilia) dates from the latter half of the seventh century and

17 This type of pottery was unearthed at Fort St. Jean (Marseilles) in association with Greek and Italian sherds dating from the seventh to the fifth century B.c.

${ }^{18}$ L'Anthropologie (I9r8-I9) XXIX, p. 2 I 5 ff.

${ }^{19}$ In the fifth century the Greek influence appeared to have reached the Rhine by another route: see below, p. $437 \mathrm{f}$.

${ }^{20}$ See M. Piroutet's Contribution sur l'étude des Celtes, in L'Anthropologie (1918-r9) xxIx and (I920) xxx, especially what he has to say concerning the Alaise-Württemberg group. 


\section{MASSILIA AND EARLY CELTIC CULTURE}

shows the Greeks had established contact with that region during the half century preceding the traditional date of the colony's foundation. ${ }^{21}$ It is not impossible, therefore, that the earliest imports reached the Celtic and adjacent areas between the years $650-600$ B.c.

Judging from the increase in the number of southern imported objects found in the Celtic area during La Tène A (beaked flagons, stamnoi, etc.), the relations between those regions and Massilia would seem to have become greatly intensified. But a detailed study of these imports has yet to be made; and it is not unlikely that some of them were of Etruscan, some of wholly barbaric manufacture. Never the less, there is good reason to believe that the relations between the Celtic area and the south of France continued uninterrupted during the earliest phase of the La Tène period. The closing of the Straits of Gibraltar towards the end of the vith century, to other than Carthaginian traders, though not responsible for the opening of an overland route from Massilia, no doubt gave an added stimulus to its commerce with the barbaric region to the north.

With regard to coin-finds, Cary ${ }^{22}$ considers the distribution of Greek coins in the barbaric area as a 'crucial test' for the existence of a trade between the Greek colonies of southern France and the barbaric hinterland. The earliest types (prior to $45^{\circ}$ B.C.) found in the Provence area (the treasures of Auriol, etc.) fall into two categories: those minted in the east Mediterranean area or southern Italy, and those in the barbaric style. Neither group is of much concern to us : whether we agree with Babelon in regarding the latter as struck by the west Mediterranean colonists, or, with Seltman, as actually imitated by their barbaric neighbours, neither they nor the imported types are found far enough north to be in the Celtic area. The same is true for the early Massiliote coinage (struck before 400 B.C.). ${ }^{23}$ Cary, in noting this, dismisses the view that the Massiliotes dispensed with currency when trading with the Gauls, because the latter 'showed a marked avidity for coins and set up mints at an early date'. But, at the highest estimate, the first Celtic imitations of Greek coins date shortly before

${ }^{21}$ Comptes Rendus de l'Academie des Inscriptions et de Belles-lettres (=CRAI) I9Io, p. 422 ff. and Clerc, l.c., I, p. I05. Ionian ware of the sixth century has been found on this site, at Baou-Roux, and at Vitrolles, near the Étang du Berre (Clerc, l.c., I, p. 34I).

22 Fournal of Hellenic Studies (r924) XLIV, p. I66 ff.

${ }^{23}$ Between 400 and $35^{\circ}$ B.c. two new Massiliote types were struck. These have been found in northern and central Gaul. But as they were current for several centuries, they form an unsafe basis of argument (see Cary, l.c., p. 175.) Cf. CAH vII, p. 49. 


\section{ANTIQUITY}

336 B.C., while minting can hardly have become common among the Celts prior to 300 B.C. Yet the finds from the Camp de Château show that a trade in Greek imports between eastern France and Lower Provence had been established during the sixth century. The above argument of Cary is therefore unsound; and it would be safer to ascribe the absence in Celtic lands of Greek coins earlier than the fourth century

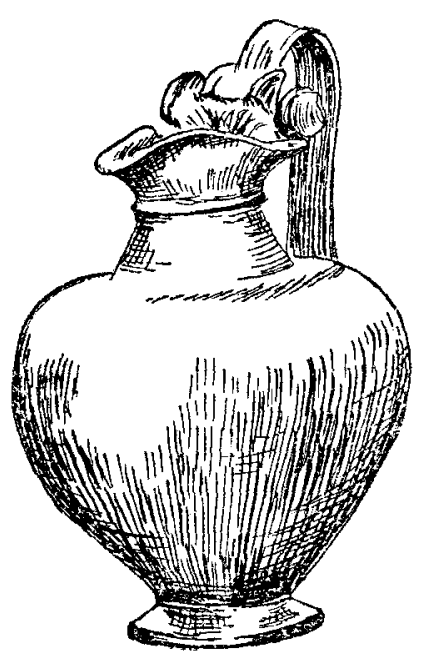

FIG. I. EARLIER TYPE OF FLAGON. VILSINGEN (RECONSTRUCTED. SEE PLATE II)*

to the fact that the Celts (not as yet in immediate contact with the Greek colonies) were not ripe for trading in currency, and still had recourse to the more primitive method of barter. The evidence of early coinfinds does not therefore affect the issue one way or the other.

We have already noted that red-figured Attic sherds were discovered in the top stratum (E) at the Camp de Château (Jura).

Greek pottery has also been found in the following Celtic burials: Somme Bionne (Marne), La Motte St. Valentin (Hte. Marne), Rodenbach (Rhenish Palatinate) and Klein Aspergle (Württemberg). ${ }^{24}$

Since Déchelette published his monumental work, an important

24 The references will be found in the last of the 4 vols. of Déchelette's Manuel. The latest of these vases dates from $c .45^{\circ}$ B.C.

* I have to thank Mrs M. C. Burkitt for this drawing. 


\section{MASSILIA AND EARLY CELTIC CULTURE}

site has been discovered at Ensérune (Hérault), ${ }^{25}$ about six miles south-west of Béziers. Here the learned and public-spirited $M$. Mouret has excavated upwards of a hundred and thirty-eight incineration graves. Among the more important metal objects are : swords of a La Tène I character, and of a curved Iberian type ; La Tène I fibulae ; girdle-clasps derived from the palmette and zoomorphic motifs, both varieties found in La Tène $\mathrm{A}$ contexts in the Celtic area. Coral is by no means poorly represented. The pottery, which is of exceptional interest, may be roughly divided into four categories : (I) red-figured Attic vases of the late fifth and fourth centuries, (2) 'Campanian' pottery of the fourth and third centuries, (3) Iberian pottery of the same date, (4) vessels of indigenous manufacture. With regard to the red-figured Attic vases, it should be noted that this was not the earliest type of Greek pottery to reach south-west France : examples of blackfigured Attic ware have been found at St. Gabriel (near Tarascon), Béziers, Montlaurès and Clermont-Dessous (Lot et Garonne). ${ }^{26}$ Although Mouret is probably correct in regarding Ensérune as an Iberian settlement, ${ }^{27}$ he rather under-estimates the possibility of Celtic influence. The La Tène I swords and a gold earring (like Déchelette, l.c., II, 3, fig. 542.2) assuredly point to relations between Ensérune and the Celtic world. I have spoken of Ensérune at some length. Owing to the finds from this site, it has been suggested that the cradle of the La Tène culture might lie further to the south-west than is generally supposed. ${ }^{28}$ Until earlier burials have been discovered, one should beware, when speaking of the genesis of the La Tène culture, of overemphasizing the importance of Ensérune: the majority of the graves date from the fourth and third centuries, the most ancient from the end of the fifth, whereas the Middle Rhenish 'Chieftains' Graves' and the rich chariot-burials of the Marne culture date from the fifth, Reinecke even placing the earliest of them in the second half of the sixth century. ${ }^{29}$

${ }^{25}$ CRAI, I916, pp. 397 and 469 ; I9r8, p. 95; 1919, pp. 223 and $293 ;$ I920, p. 3 I ;

I927, p. I. Fondation Piot : Monuments et Memoires (1924) xxvII, p. $45 ;$ L'Illus tration, 24 April, 1926 ; Corpus Vasorum antiquorum, fasc. 6 (1927).

${ }^{26}$ Clerc, l.c., I, pp. $342,346,348$; Déchelette, l.c., II. 3, P. I 598.

27 Apart from the Iberian pottery and certain of the metal objects, Iberian inscriptions occur on some of the cinerary urns.

${ }^{28}$ CRAI, I9I8, p. $96 \mathrm{f}$.

${ }^{29}$ This should be borne in mind when speaking of the place of origin of the above zoomorphic girdle-clasps. Mouret does not seem to realize this : cf. Mon. et Mem. Piot, xxviI, p. $5^{2}$. 


\section{ANTIQUITY}

Another site in this district, where Greek influence is to be seen, is Montlaurès, about $2 \frac{1}{2}$ miles west of Narbonne. ${ }^{30}$. Here the foundations of the huts, cut into the rock, closely resemble a type of foundation discovered at Athens (see Déchelette, l.c., II, 2, fig. 422). The earliest Greek pottery found here (black-figured ware) dates from the sixth century; but the majority of the sherds of Greek and Italo-Greek vases from the latter part of the fifth, to the third century.

Further to the east, in the Lower Rhône area, important finds came to light on the hill-fort of Baou-Roux, (near Marseilles). The earliest sherds found on this site belong to the Italian geometric cycle of pottery ; but fragments of painted Ionian ware, black- and red-figured Attic vases, and later Cumaean pottery, were also discovered, not to mention other objects. ${ }^{31}$

Apart from Baou-Roux, the following sites in or near the Lower Rhône valley have yielded red-figured Attic ware :-Courtines and Petit Cerveau (both near Ollioules), Caumont, St. Jacques (close to Cavaillon) and Nimes. Further up the Rhone, Greek amphorae, or amphorae made in Greek colonies in southern Italy, occurred on three sites to the north of Uzès :-Chusclan, Bagnols-sur-Cèze and Laudun. ${ }^{32}$ North of these, I know of no Greek pottery of this period until we come to the Celtic area.

Classical writers speak of the Celtic peoples' great love of wine, and the evidence of archaeology not only bears out what they have to say on this point, but shows that there is a long history behind these references. Most of the imported vessels, whether pottery or bronze, were ultimately connected with the carrying,storing, mixing and drinking of wine. If, as in the case of the La Motte St. Valentin stamnos, they were used for cinerary urns, it does not mean that they were imported for that purpose, nor does it follow that they were all imported solely as objets d'art. In the 'Chieftains' Graves', we sometimes find a regular table service of bronze vessels; while the fragments of undecorated amphorae from other than sepulchral sites (Camp de Château and Mont Guérin) prove that the vessels can hardly have been imported as anything else than receptacles for the produce of the South. ${ }^{33}$ But

${ }^{30} \mathrm{CRAI}, \mathrm{I} 909$, p. $98 \mathrm{I}$.

31 Annales de la Faculté des Sciences de Marseille, XIII, fasc. 3, p. $84 \mathrm{ff}$.

${ }^{32}$ Clerc, l.c., I, pp. 340-5, and Joulin, RA (I9I0), II, p. 7 f.

${ }^{33}$ Even supposing that some of these amphorae were used for the transportation of oil and not wine, we know that olive oil was one of Massilia's staple exports (see Clerc, l.c., I, p. 279 f.) 
PLATE III

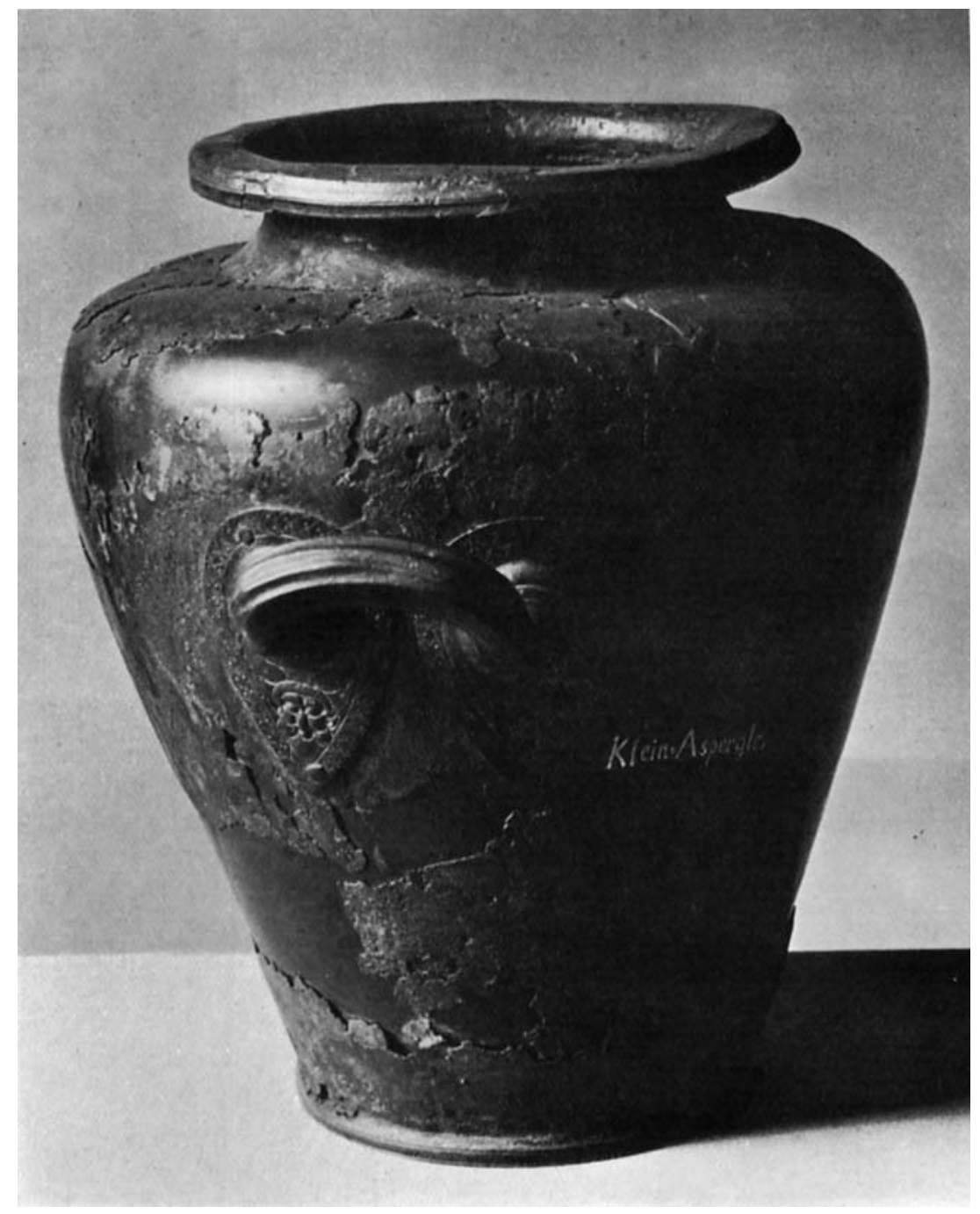

THE 'STAMNOS' FROM KLEIN ASPERGLE (WÜRTTEMBERG) By countesy of the Landeskunstsammlungen Authoritues, Stwitgart

facing $p .435$ 


\section{MASSILIA AND EARLY CELTIC CULTURE}

is this true for such works of art as some of the bronze vessels or the decorated Greek pottery ? In the 'Chieftains' Grave' at Weisskirchen (Rhein-provinz) the bronze stamnos was found to contain a resinous substance. ${ }^{34}$ This, on chemical analysis, proved to be white pitch. ${ }^{35}$ We know from classical sources that the ancients sometimes pitched their wines. Pliny (Hist. nat. XIV, 24) tells us that the Greeks, to give briskness to their wines when too flat, mixed them with potters' earth, pounded marble, salt or sea-water, the Italians with brown pitch, and that it was "the universal practice both there (in Italy) and in the neighbouring provinces to season their wine with resin'. But later in the same work (XIV, 25), still speaking of wine, he tells us that the best quality of pitch is that from Mount Ida, though Vergil (Georgic II, 498) speaks of Narycian pitch. The latter reference is of interest. Narycia is the poetical name for the Greek colony Locri in southern Italy, and it has lately been suggested that many of the archaic Greek bronze vessels may have been made at Locri rather than, as hitherto supposed, at Tarentum. ${ }^{36}$ Locri was in Bruttium, a region according to Pliny (l.c., XIV , 25) that produced the most highly esteemed pitch in Italy in preparing vessels for the storing of wine.

The contents of the Weisskirchen stamnos not only shows that this practice dates back to the fifth and possibly even into the sixth century, but that those vessels were used by the Celts for wine, and seem, originally, to have owed their introduction into the Celtic area to the wine trade, which, as the amphorae from the Camp de Château and other sites show, probably started in phase $D$ of the Hallstatt Period. If this conjecture is correct, the La Tène art may largely have owed its existence to Celtic thirst.

But from what region was this wine imported? We have good reason to believe that, although the vine was known in France in Quaternary times, the art of viticulture was first introduced into that country by the Massiliotes (Justin, XLIII, 4.2). It seems to have been confined to the Massilia area until $c$. I20 B.C. ${ }^{37}$ Although Martial has little good to say of the Massilian wine, Posidonius the Stoic (apud Athenaeum, IV, 36) tells us that the Celts drank wine imported from that region, and also from Italy. Posidonius was born about I35 B.C.

${ }^{34}$ The stamnos from Klein Aspergle (plate III) also contained a resinous deposit.

${ }^{35}$ Déchelette, Collection Millon, p. 123.

${ }^{36}$ Neugebauer, Archaeol. Anzeiger, 1925, col. $201 \mathrm{f}$. worth.

${ }^{37}$ Billiard, La Vigne dans l'Antiquité, P. 8I. I owe this reference to M.P. Charles- 


\section{ANTIQUITY}

and was still living in the year 62. He travelled widely in Gaul, and as the civilization of the Celts depicted by Diodorus Siculus (who seems to have drawn his information from Posidonius' lost work) is that of La Tène II rather than the La Tène III, Posidonius' travels in Gaul may date from $c$. 100 B.C., or possibly a little earlier. By that time Italian wines had become famous, ${ }^{38}$ but before the middle of the second century viticulture played little part in the economic life of Italy, the wine then drunk being almost entirely imported from Greece. Pliny (Hist. nat. XIV, 9) tells us that Apollodorus in his list of wines recommended to King Ptolemy (323-285 B.C.) does not mention any Italian varieties, as at that time they were not known (Italicis etiam tum ignotis). If this was true for the turn of the fourth and third centuries, how much less must viticulture have been practised by the non-Hellenic inhabitants of Italy from the seventh to the fifth centuries. During early times in Italy, wine seems mainly to have been used medicinally, and it is thought that Numa in his laws ordained that milk should be used in place of it at sacrifices owing to its rarity. The evidence all points to the Celts of our period importing their wine from the region around Massilia, or through Massilia from Greek lands ; and it is highly probable, therefore, that during the late sixth and the fifth century, when so many vessels of southern origin connected with wine were found in the Celtic area, the trade between that area and Massilia was maintained if not intensified.

Another substance imported by the Celts was coral..$^{39}$ Bronzes encrusted with coral frequently appear in La Tène I contexts in the Champagne and other areas. Pliny the Elder writes (Hist. nat. XxxII, I I) that this substance reached the Gauls from the Stoechades (the Îles d'Hyères), but coral also occurs off the Lesser Stoechades (the islands near Massilia). It is found today off the Ile Maire, and those who seek it have seen and sometimes recovered amphorae lying 20 to 30 metres deep, although so far only types from the first century A.D. have been discovered. ${ }^{40}$ But the Greater Stoechades were the most important coral fisheries of ancient times. Later, according to Pliny, the demand from India deflected the trade in coral from the Celtic region ; indeed, as Reinach has shown, there is a great falling off in the

38 Billiard, l.c., p. 7r.

${ }^{39}$ See S. Reinach's interesting study, Le Corail dans l'industrie Celtique. Rev. Celtique (1899) xx, pp. $22 \mathrm{ff}$. and I 7 ff.

${ }^{40}$ Clerc, l.c., $\mathrm{I}, 287 \mathrm{f}$. 


\section{MASSILIA AND EARLY CELTIC CULTURE}

number of objects of this substance found in the Celtic area during La Tène II and III. ${ }^{41}$ But it is interesting to note that coral first appears in the Celtic region during phase $\mathrm{D}$ of the Hallstatt period, the phase in which the Greek influence from the south of France first reached eastern France and south Germany.

Judging from the distribution of southern imports certain modifications in the routes took place during La Tène A. Although the main route still passed up the Saône into the Franche Comte and the neighbouring districts, the demand from a new district, the Champagne area, had also to be met with. A number of finds have been dredged up from the Saône at Chalon (Saône et Loire) ; most of them date from La Tène II and III ${ }^{42}$ but La Tène $\mathrm{I}$ objects are not lacking. Chalon is known to have been a point where a number of routes converged and it is not unlikely that the highway which connected the Champagne area with the Saône-Rhône complex, branched off from the former river at that point. Groups of southern imports to the west of the Loire and in the Garonne area would, from their geographical position, testify to connexions with the south of France rather than the Alpine passes. Further east, we have the Middle Rhenish 'Chieftains' Graves' with their many southern imports. But as they lie north of a line from Hagenau to Ulm, it is not likely that the route by which the southern imports came, struck the Rhine as far south as it did in the Hallstatt Period (see above p. 430). During phase A of the La Tène Period, it would appear to have continued up the Saône (as well as branching off up the Ain), and struck across Lorraine towards Metz. From this point it reached the Rhine through at least four channels. The chief of these passed through the Birkenfeld-Nahe country, the heart of the Central La Tène $\mathrm{A}$ area; the other three made the Rhine to the east of Hagenau, near Worms and at Koblentz respectively. ${ }^{43}$

It remains to discuss the importance of the part played by the Ticino-Mesocco-Bernardino-Rhine route during Hallstatt $\mathrm{D}$ and $\mathrm{La}$ Tène A. From a purely geographical point of view, the Rhône-Saône route is the most direct way for southern imports to have reached the

41 The use of coral did not die out completely. It is found, for instance, on the Witham Shield.

42 Hundreds of broken amphorae were found at this point. They date, however, from the first century B.c.

${ }^{43}$ Schumacher, Siedlungs und Kulturgesch. der Rheinlande, I, pl. 8. Judging from the imports in the Berne area, the Rhône-Aar-Rhine route was less important in La Tène $A$ than Hallstatt D. 


\section{ANTIQUITY}

Celtic area in France; but Switzerland and south Germany might equally well have been supplied by the way of the former route. From the distribution of the cordoned bucket, the Etruscan gold pendants found in the Canton of Berne, ${ }^{44}$ the occurrence of Etruscan spits at Chalon-sur-Saône and Somme-Bionne, not to mention the possibility of some of the beaked-flagons found in the Transalpine region being Etruscan or even upper Italian copies of Greek or Graeco-Italian prototypes, it might be argued that the Bernardino-Rhine route was of capital importance.

It is difficult to determine the direction by which the cordoned buckets reached the Celtic area. Whatever their place of origin, they are best represented in the Bologna and Este regions, and it would seem almost certain that it was from there that the examples found in the Transalpine area came; while some of them beyond a doubt must have entered the latter region by way of the Central and Eastern 'amber routes' ${ }^{45}$ The examples found on Hallstatt $\mathrm{D}$ and La Tène A sites in south Germany may well have come by the former way along its upper Danubian extension. But the occurrence of this type of vessel on a number of sites to the west of the Rhine ${ }^{46}$ might point to their reaching that area by way of the Ticino-Bernardino-Rhine route, especially as examples have been found in the Bellinzona district. ${ }^{47}$

The occurrence of southern imports in that district is not as valuable as might on first sight appear. Neither Déchelette nor Ulrich realize the complexity of the problem presented by these and other Alpine finds ; nor is it fully grasped by Randall-Maclver in his masterly Iron Age in Italy. Owing to the marked conservatism of these Alpine districts, objects are often found in association which elsewhere would be two to four centuries apart. Thus the chronology of the Bellinzona cemeteries is extremely obscure, and it is almost impossible to say if a grave containing Late Hallstatt objects actually dates from that and not a later period. Reinecke assigns a late date to this whole group of cemeteries. The chronological evidence afforded by finds in this zone

44 See Déchelette, Manuel, Ir, 2, p. 283 f. A similar object (though in bronze) has come to light at Peterinsel (Tschumi, l.c., p. 132). Tschumi thinks these pendants are barbaric imitations of Etruscan work, but Forsdyke, in a letter to me, regards them as actually Etruscan. At Ins and Jegenstorf they were found in Hallstatt D contexts.

${ }^{45}$ See my map facing p. 484 in the Geographical fournal, 1925 .

${ }^{46}$ Déchelette, l.c., II, 2, p. 77 I ff.

${ }^{47}$ In graves 61, 62 and 68 at Molinazzo. A fourth example was also found there. $R e$ the chronology of these cemeteries, see Mainzer Festschr, 1902, p. I02. 


\section{MASSILIA AND EARLY CELTIC CULTURE}

is therefore unreliable, an objection which applies to the beaked flagons as well as the cordoned buckets from the Bellinzona cemeteries. Again, if the latter came by the Bernardino-Rhine route, how is it that we find no examples of the contemporary ' situla style' in the regions which that route would normally supply? For examples of the "situla art' abound in precisely those regions of upper Italy in which the cordoned bucket is most frequently found. No examples of this interesting style have occurred as yet in the area west of the region supplied by the Central 'amber route': it is quite foreign to France, Switzerland and the western parts of southern Germany. It seems not unlikely, therefore, that the cordoned buckets reached the upper Danubian zone by the Central route, and, that passing up the upper Danube, they eventually found their way into France. We know that close relations existed at that time between eastern France and the upper Danubian area.

Again, although Greek pottery of the seventh to the fourth century is found in France and southern Germany, the hundreds of graves in the Ticino area have not as yet furnished a single Greek sherd of those dates.

But there is a still greater objection to the Bernardino-Rhine route being the highway along which the stimulus travelled that played so great a part in the genesis of the La Tène culture. Schumacher has shown that in Transalpine Switzerland and southern Germany, south of a line through Hagenau, Rastatt and Stuttgart to Ulm, the civilization of La Tène $A$ is virtually unrepresented, and that in its place we find a survival of the Hallstatt $\mathrm{D}$ culture. ${ }^{48}$ If the stimulus which contributed so largely to the birth of the La Tene style came by the Bernardino-Rhine route, is it possible that the earliest phase of the La Tène culture should be altogether lacking in those regions which lie closest to the point where that route debouches from the northern slope of the Alps? It may be argued that this phase is equally lacking in the Rhône valley between Orange and Lyons. But in the former region we find a pertinacious and comparatively well-represented Hallstatt D culture, whereas in the Rhône valley hardly any grave-finds are known between the above two points. This may partially be due to the latter not having been as systematically explored, but in event of no such finds materializing, the district in question must be regarded as a 'corridor-district'. If the Rhône is in our days prone to flood, the bad climate of the Sub-atlantic period ${ }^{49}$

${ }^{48}$ Ebert, Reallexikon, viIr, pp. 264-6.

${ }^{49}$ For these conditions, see C. E. P. Brooks' Climate through the Ages, 1926, p. 339 f. 


\section{ANTIQUITY}

must have rendered it a great menace to fixed settlers. Early traders were more or less birds of passage, and were free to choose favourable times for their long and often perilous journeys.

We are now faced with a difficulty : an influence from those parts of Italy outside the area of Greek colonization is still to be reckoned with. How could it have reached the Celtic region without crossing the Alps? Were the above Etruscan and Italian imports, other than cordoned buckets, shipped to Massilia, thence reaching the Celtic area by the above-mentioned routes? Was there a connexion between Massilia and central Italy as early as the sixth and fifth centuries B.c.? The most serious objection to such a possibility is historical rather than archaeological. After the fall of Phocaea in 540 B.C., part of that city's inhabitants founded a colony at Alalia in Corsica. In 535, the Carthaginians and Etruscans united against them ; a battle was fought off the coast of Sardinia which resulted in two-thirds of the Phocaean fleet being destroyed, and the seizure of Sardinia and Corsica by the Carthaginians and Etruscans respectively. But the allies suffered such severe losses that Herodotus tells us the Phocaeans won the battle. If they did, it was a somewhat Pyrrhic victory! After their flight from Alalia they founded the colony of Velia in Lucania. The years following the battle of Alalia were doubtless critical ones for the Phocaean colony Massilia, and scholars have stated that her commercial enterprise was greatly curtailed thereby. But, as far as Massilia's eastern connexions were concerned, this should not be over stressed. It was the Alalians, not the Massiliotes, who were principally concerned in the above battle. We have no reason to suppose that this EtruscoCarthaginian alliance was other than ephemeral: the Etruscans took no part in the battle of Himera (480 B.c.), in which a Carthaginian fleet was destroyed by the Greeks. The foundation of a Phocaean colony at Velia was bound to further relations between that region and Massilia. The troubles of Massilia at that time lay to the West (their commercial enterprise there suffering a severe set-back from the Carthaginians), ${ }^{50}$ not in the East. The fall of Phocaea (540 B.c.) did not necessarily sever Massilia's connexion with the east Mediterranean. Although relations with the mother-city were at an end, there were other Greek states in that region whose wares the Massiliote merchant could trade with the West. It has been suggested that the Massiliotes played a part in the exportation of Attic pottery to Italy: while the

so Clerc, l.c., I, p. 329. 


\section{MASSILIA AND EARLY CELTIC CULTURE}

signatures of the artists and the inscriptions of the paintings on these vessels were in the Attic alphabet, the price-marks are in Ionian letters : Massilia was an Ionian colony, and the maritime enterprise of Athens only began after 480 B.C. ${ }^{51}$ As Randall-MacIver observes, Cumae was not the sole distributing-centre of Greek wares in Italy. There were probably 'ports échelonned all the way up the western coast at which oriental and Greek traders made it their habit to call ' ${ }^{52}$ In the Campania region he sees various manifestations of Etruscan influence: ' a whole class of handsome black bucchero in Campania which has never been sufficiently studied, shows strong Etruscan influence, though it is evidently of local manufacture '.53 In this connexion we should note that bucchero-ware came to light among the finds at Fort St. Jean (Marseilles), ${ }^{54}$ and that Italian geometric pottery of the sixth century was found at Baou-Roux. ${ }^{55}$ Finally, although one should be wary of taking the evidence of Livy (I, 45) and Justin (XLIII, 3.4 and 5.I) too literally, the friendship between Massilia and Rome goes back to very early times. On the whole, therefore, it is not unlikely that there were over-sea trade connexions between Massilia and those parts of Italy outside the area of Greek colonization. Nor should one ignore the possibility of Etruscan and Italian objects reaching the Celtic area from the seventh to the fifth centuries by sea through Massilia, for in our present state of knowledge there is less to be said against their coming by this route than by upper Italy, the Bernardino and the Rhine. ${ }^{56}$

When we have proof of the existence of the La Tène A culture in south-westernmost Germany and in Switzerland, when definite evidence is forthcoming as to Upper Italy being a centre of manufacture of bronze vessels copied from Greek prototypes, and when the tangled chronology of the south Alpine cemeteries has finally been unravelled, it may be possible to regard the stimulus which contributed to the genesis of La Tène culture as also having reached the Celtic area by the Bernardino-Rhine route. But, until these three obstacles have been

51 This suggestion is advanced by Miss Adams in her Study in the Commerce of Latium (Smith College Classical Studies, II, p. I I).

${ }^{52}$ Randall-MacIver, Iron Age in Italy, p. 167.

53 Ibid. l.c., p. 168.

${ }^{54}$ CRAI, I9IO, p. 430. Vasseur is inclined to assign it to the seventh and sixth centuries.

${ }^{55}$ Déchelette, l.c., II, 3, p. Ioor.

56 The so-called Campanian vessels found on more than one site in southern France date from the fourth and third centuries. They are of Graeco-Italian origin and were made in Campania, Lucania and Apulia. 


\section{ANTIQUITY}

overcome, it is safer to regard that route as being of secondary importance, when compared with the influence which was transmitted to the Celtic world by the Greek colony of Massilia..$^{5}$

In the centuries following the Gaulish invasion of Italy, the importance of the Bernardino route seems to have reasserted itself. The reason for its lack of prominence in our period is not easy to find. Gams and Nordhagen ${ }^{5} 8$ hold that the Sub-atlantic 'climate-crash', which took place $c .850$ B.C. and reached its second rainfall maximum $c .500$, affected trade over all the Alpine passes above 2000 metres. The height of the Bernardino is 2063 metres.

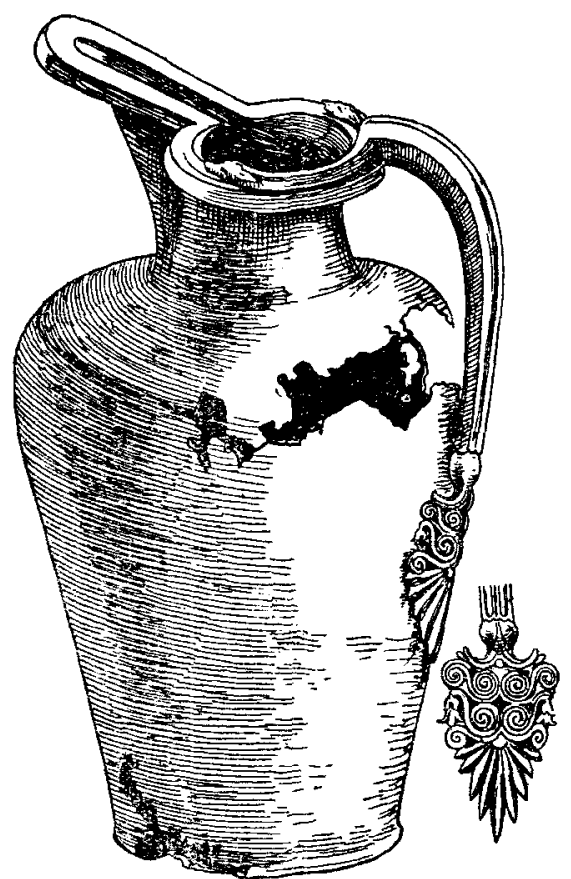

Fig. 2. LATER TYPE OF FLAGON. FROM SOMME BIONNE By courtesy of the British Musewn Authorities

${ }^{57}$ In Reinecke's opinion the finely incised zoomorphic style, as seen on the girdleplate from Cerinasca (grave 93) and the Rodenbach field-flask, may have come from north-west Italy, presumably by the Bernardino-Rhine route. 'This type of art played but a slight rôle in the development of the La Tène style.

${ }^{58}$ Postglaziale Klimaänderungen (Geograph. Gesell. Munich, xvI 2, I923), p. 220 f. 